\title{
Identification and Use of Plant Material for the Manufacture of New Zealand Indigenous Woven Objects
}

\author{
Rua E. McCallum and Debra J. Carr
}

\section{Research}

\begin{abstract}
Significant collections of objects manufactured by Māori (the indigenous people of New Zealand) are held, prized and exhibited internationally by cultural institutions including museums such as B.P. Bishop, British, Field and PittRivers Museums; and Te Papa Tongarewa (Museum of New Zealand). This article aims to assist with the identification of woven objects originating from New Zealand and with the plant material(s) typically used to construct them by gathering mātauranga Māori (traditional knowledge) and diverse interdisciplinary academic literature e.g., botany, textile science, anthropology, conservation science, museum studies. Plant descriptions, harvesting, processing and use are discussed; thereby informing the researcher and affording appropriate respect and representation to the plant from which the object is derived. Availability of such information informs museum collection and interpretation practices, and assists with material culture investigations.
\end{abstract}

\section{Introduction}

The primary author who writes from an auto-ethnographic perspective is Ngāi Tahu, a tribal group whose boundaries encompass much of Te Wai Pounamu (South Island of New Zealand). She is a contemporary practitioner and researcher of Māori cultural materials and their use. Some of the terminology and names used in this article are unique to Ngāi Tahu and the southern tribes who additionally claim a genealogical connection to Rapuwai, Hāwea, Waitaha, and Ngāti Māmoe. An insider approach has been adopted, thus emphasis has been placed on the Māori word usage and its primary placement, as opposed to English. Thus, where a Māori word appears textually for the first time, a parenthetical English translation will be provided in text; furthermore, a glossary is supplied at the end of the paper.
Māori are a tribal people indigenous to New Zealand having migrated from various islands in Polynesia approximately 1000 years ago. Toward the end of the eighteenth century European whalers and sealers arrived, followed by colonists mainly from Great Britain. A treaty was signed at Waitangi in 1840 between the Crown and Māori when sovereign rule under Queen Victoria and protection of the native population came into force. At that time intermarriage was not unknown between races and today there are very few full-blooded Māori living. Tribal lifeways were assimilated into Western culture, society and government. Although, treaty grievances have mostly been addressed and a cultural renaissance including the revival of Māori language has occurred, traditional Māori life will never be what it once was. Today, modern Māori have a lifestyle closely resembling their Pākehā (non-Māori) counterparts under Western law, but Māori continue to adhere to core traditions, customary practices, lore and the spiritual values of their ancestors.

\section{Correspondence}

Rua E. McCallum, Ruaimoko Productions and Consultancy Ltd., PO Box 1388, Dunedin, NEW ZEALAND.

rua.moeraki@xtra.co.nz

Debra J. Carr, Clothing and Textile Sciences, University of Otago, Dunedin, NEW ZEALAND. [Now Department of Engineering and Applied Science, Cranfield University, Shrivenham, SN6 8LA, UNITEDKINGDOM.]

d.j.carr@cranfield.ac.uk

Ethnobotany Research \& Applications 10:185-198 (2012)

Published: May 15, 2012 
The Māori worldview is defined by a direct relationship through whakapapa (genealogy) with the environment which according to oral tradition was inherent at the beginning of the universe. Art motifs associated with their material culture are rooted in the natural world as are physical objects, tools, buildings and resources.

It is important for iwi Māori (Māori people) to preserve the past traditions of their people including both material artifacts and the non-material knowledge system that underpinns Māori beliefs and customs. All of this is at risk, and has been since New Zealand became home to more than one culture. There are developing strategies in New Zealand for museums and Māori to achieve a level of participation in the management, care, interpretation, presentation and preservation of taonga Māori (Māori treasures) (O'Regan 1997). It still remains that museum collections of Māori artifacts, nationally and internationally are poorly understood by the 'other' cultures working with them. This article therefore, addresses a small proportion of Māori cultural artifacts by exploring woven objects (including basketry, mats and clothing) and the plant material used to manufacture them.

Such items are manufactured from either strips of plant material or fiber extracted from plants using the processes of raranga (weaving using leaf strips) and whatu (weaving with fiber) respectively. The positive identification of taonga and the materials used to manufacture them is important with respect to their care and preservation within cultural institutions such as museums. Further, such appropriately assigned knowledge using the correct linguistic terminology provides a platform for informing employees and visitors to cultural institutions about the material culture of a society, and the preservation, enhancement, maintenance and revival of traditional knowledge (Balázsy \& Eastop 1999, Florian et al. 1990, Hodges 1988).

The ability to identify plant material used to manufacture objects is acknowledged as difficult within many cultural contexts and especially holders of artifacts both domestic and foreign. For objects originating from New Zealand, such identification is further limited by a paucity of information easily accessible in the international literature. However, some efforts have been made to provide guides for the identification of plant material derived from New Zealand (Carr et al. 2009, Goulding 1971). In some instances identification of objects constructed from cultural materials originating from New Zealand may assist in distinguishing tribal ownership with respect to rohe (tribal areas). This may provide access to lost knowledge, thus enabling social inclusion by preserving, enhancing and maintaining the traditional knowledge and customs of cultural resource use for future generations. However, care is required with respect to both cultural materials and finished artefacts as these were widely traded nationally and internationally by both Pākeha and Māori. Further caution is advised, once tribal identification has been confirmed this can raise issues of ownership as opposed to kaitiakitanga and possible repatriation to tribal authorities, communities or individuals. The term kaitiakitanga is complex, it simply means guardianship, but at a deeper level includes trusteeship and possessing the authority over their taonga. From an iwi Māori perspective, taonga held within a cultural institutional context belong to them, they are connected to the objects, and the organization that often understand themselves to be the legal owner, they are holders of those artefacts. The fundamental difference is the perception of 'belonging and ownership' which in the Māori view is intrinsic; specific taonga may have been made by an ancestor and therefore analogous to a family heirloom.

Generally, objects are crafted from natural materials with due consideration to the atua (gods) as spiritual guardians of the environment and accompanied by ceremonial practice. The craftsperson works within the restrictions of these protocols using knowledge that has been handed down generationally as taonga tuku iho (treasures handed down), a legacy from the atua. The customs and rituals undertaken when producing a simple rourou (basket for eating from) are no less important than those for creating a precious artwork; all taonga are meaningful due to their origin, the respect for the natural materials used, the knowledge and craft applied in its making and the essence of its new form as having been transformed from its primal state. The ethos of these Māori values has remained unchanged throughout time.

Consequently, the plants discussed in this paper are significant to Māori both traditionally and in contemporary society; they are taonga species listed in the Ngāi Tahu Claims Settlement Act 1998 (New Zealand Government 1998) which acknowledges Ngāi Tahu's cultural and traditional use of native floral and faunal species. The Act identifies these species by name and acknowledges the cultural, spiritual, historical and traditional association of Ngāi Tahu with those species and the natural world.

"Taoka embody powerful forces, and represent some of the genealogical identity and relationship to resources originating in the environment. The interconnectedness of humans to the natural world occurs through a whakapapa relationship, whereby all things trace their origins to the atua. All taoka are imbued with spiritual concepts such as mana, seen as authority, power, prestige, and is the source of energy transmitted through ancestors from the gods; tapu [under restriction] and rāraki kōrero [traditional stories]." (McCallum 2008:23).

This statement is echoed in the understandings of Māori across New Zealand, indeed Kawharu relates this relationship with health.

"The interconnectedness of all things means that the welfare of any part of the environment will directly impact on the welfare of people. The health and wellbeing of natural resources will impact on the health 


\section{McCallum \& Carr - Identification and Use of Plant Material for the Manufacture of New Zealand Indigenous Woven Objects}

and well-being of Māori depending on these resources" (Kawharu 2000).

This is important in maintaining a holistic balance between environment and mankind, and for native conservation practices which are still undertaken by Māori today.

Traditionally and in modern society, strict tikanga (protocols) are adhered to when harvesting, gathering and working with plants. This is a lifeworld practice carried out as a normal function and is not confined to plants, but Māori customs in general. With specific regard to harvesting and gathering plant material, respect was afforded to the environment, and the health and sustainability of the plants were paramount to maintaining the longevity of the resources and craft generationally. Often the passive ritual of giving thanks offered by the harvester to the atua, will go unnoticed by onlookers and the distinction in tikanga vary across tribal boundaries and across species.

Traditional Māori were both hunter gatherers and agriculturalists. Their environmental knowledge and conservation ethic was transplanted into the New Zealand landscape from Polynesia, however the New Zealand climate was not ideal for several transported botanic species. Cultivating kumara (sweet potato) was not possible south of Banks Peninsula in the south and

"no coconut, banana, breadfruit, or pandanus used for weaving survived. Taro, yam, gourd, tropical Cordyline, paper mulberry only grew in the North Island." (Anderson 2002)

Except for cultivated food plants, Māori did not practice a system of agriculture using garden plots, but developed areas through propagation where a plant might naturally be found. For example, a pā harakeke (flax plantation) might be extended in size simply by propagating fans from existing bushes in the plantation. These would within five years be fully grown bushes yielding a harvestable crop for weaving. A traditional 'garden' might be as large as a province, where the harvester would seasonally gather food and resources on an annual basis, often moving outside his or her province into neighboring areas. The latter practice was only done if the harvester had a genealogical right to harvest from other areas otherwise resources might be traded. This methodology applied to plants for food, medicine and weaving.

Generally harvesting methods have remained unchanged, but some modern tools have replaced traditional. The weaver is solely in charge of the materials he/she harvests, the processing and finally the weaving. This would differ in large communal projects such as sail making, house building, raft making, etc. Harvesting occurs mainly in warmer months and plant processing techniques were specific to each plant as can be seen under each plant heading.

\section{Methods}

The aim of this article is to describe objects and the plants used to manufacture them using the process of raranga or whatu, and focuses primarily on southern Māori sources. This article is a proportional result of the data collected for a cultural resource kit collated by the primary author, and from her personal knowledge as a user of cultural material. Some of the gathered facts were collected from other users of cultural information initially interviewed by the primary author; these informants include kaumātua (elders) and tohunga (skilled persons, chosen experts). Thus, the article combines mātauranga Māori with western academic literature from a number of disciplines including, but not limited to, botany, textile science, anthropology, conservation science and museum studies. This combination of knowledge sources acknowledges and combines information available within both world views.

The results of this transdisciplinary investigation commence with a summary table linking object type to plant. Specifically, data is tabulated by broad object type; this allows a cultural institution employee or member of the public to identify the likely plant origin based on the object presented to them (Table 1). Then, for each plant used by Māori, botanical descriptions, traditional harvesting and manufacturing practises and descriptions of objects manufactured from the plants, are provided. Provision of such information assists with museum collection, exhibition and interpretation practices, and material culture investigations.

It must be noted that the uses of the plants in this article are more diverse than just the manufacture of woven objects. The plants described in this article constituted a vital role in everyday life for traditional Māori. Plants were, and still are, used for buildings, artworks, tools, ornamentation, weapons, rongoa (medicines), kai (food), waka (canoes) taonga pūoro (musical instruments), and had spiritual uses in religious practice. Cultural practices have continued across time, but contemporary Māori predominantly live within a Western paradigm and weaving especially has become an art. Further, the range of plants and their function by Māori was and remains more prodigious than can be covered in this review. For information outside the scope of this article the reader is directed to the further reading list provided by the authors at the end of this article and other specialised texts (e.g., McCallum 2008, Riley 1994). 
Table 1. Preliminary identification of woven objects from New Zealand.

\begin{tabular}{|c|c|c|c|c|c|c|c|c|c|c|c|}
\hline \multicolumn{2}{|l|}{ Object 'type' } & \multicolumn{10}{|c|}{ Possible plant sources } \\
\hline & & \multirow{2}{*}{ 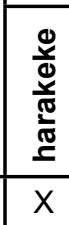 } & \multirow{2}{*}{ 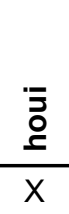 } & \multirow{2}{*}{$\frac{\text { 㐫 }}{\frac{x}{x}}$} & \multirow[t]{2}{*}{ 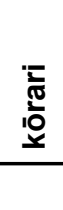 } & \multirow[t]{2}{*}{$\underset{\underline{Z}}{\stackrel{\mathbb{Z}}{\vec{Z}}}$} & \multirow[t]{2}{*}{ 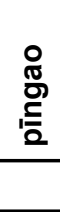 } & \multirow[t]{2}{*}{$\begin{array}{l}\text { 'O } \\
\frac{2}{2} \\
\mathbb{1}\end{array}$} & \multirow[t]{2}{*}{ 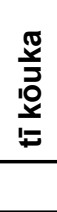 } & \multirow{2}{*}{$\frac{\vec{\partial}}{\underline{\underline{\varepsilon}}}$} & \multirow{2}{*}{$\frac{\text { iō }}{x}$} \\
\hline kākahu & cloaks & & & & & & & & & & \\
\hline kete & baskets & $X$ & $X$ & $x$ & & $X$ & $X$ & & & & \\
\hline kopare & head bindings & & $x$ & & & & & & & & \\
\hline kupenga & nets & $x$ & $x$ & & & & & & & & \\
\hline manutukutuku & kites & & & & & & & $x$ & & & \\
\hline maro & loin cloths & $x$ & & & & & & & & & \\
\hline mokihi & rafts & & & & $x$ & & & $\mathrm{X}$ & & & \\
\hline pāraerae & sandals & $\mathrm{X}$ & & & & & & & $x$ & & \\
\hline poho taupā & chest shields & & & & & & & & & $x$ & \\
\hline poi & string balls & & $x$ & & & & & $x$ & & & \\
\hline rā & sails & & $x$ & $x$ & & $x$ & & $\mathrm{X}$ & & & \\
\hline rāpaki, piupiu, kinikini, pakipaki & kilts & $\mathrm{X}$ & $x$ & & & & & & $\mathrm{X}$ & & \\
\hline tatua & belts & $\mathrm{x}$ & $x$ & & & & & & & & \\
\hline tāupa-tāhau & leggings & $x$ & & & & & & & $x$ & $x$ & \\
\hline taura & cord, rope & $x$ & & & & & & & $x$ & $x$ & $\bar{x}$ \\
\hline tukutuku & decorative panels & & & $x$ & & & $x$ & & & & \\
\hline \multirow[t]{2}{*}{ whariki } & mats & $x$ & & & & $x$ & $x$ & & & & \\
\hline & carrying slings & & $x$ & & & & & & & & \\
\hline
\end{tabular}

\section{Results and discussion}

\section{HARAKEKE}

COMMON NAME: Lowland flax, flax, New Zealand hemp BOTANICAL NAME: Phormium tenax J.R.Forst. \& G.Forst FAMILY: Xanthorrhoeaceae

\section{Habitat and distribution}

Harakeke thrives in swamps and lowland flood areas. Stiff, erect fan-like leaves grow 1-3 m long and are 5-12 $\mathrm{cm}$ wide, the butt end of the leaf is thicker and stiffer (Moore \& Edgar 1970). Koladi or kōrari (flower stalks, known botanically as infloresences) grow to $5 \mathrm{~m}$ in length; flowers (2-5 cm long) are (generally) dull red, while uaka (seed pods, capsules) are trigonous, dark and not-twisted (Moore \& Edgar 1970). In comparison wharariki grows on coastal cliffs and in mountainous areas; has drooping, floppy leaves (2 m); short koladi (2 m); green / yellow flowers and twisted uaka (Moore \& Edgar 1970). Bundles of sclerenchyma fibers lie parallel to the keel of the leaf, and are composed of elongated hollow cells (ultimate fibers) overlapping in a spiral manner (Carr et al. 2005, 2009, Cross 1912, Hutton 1869, Nottidge 1869). The ultimate fibers are bonded together by a combination of hemicelluloses and lignin that dissolve slowly in boiling water, and more rapidly in alkali solutions (Hutton 1869, 1870, 1871). The cellulose content has been reported as 51-55\% (Carr et al. 2005) and 72-73\% (Brandt 1937).

\section{Harvesting (Pendergrast 1987, 2005 , Puketapu-Hetet 1989, Te Kanawa 1992)}

Harakeke is harvested after flowering (usually in spring) and before the first frost of winter. There are rigid protocols surrounding spiritual factors controlling the process of weaving, from the first leaf cut to the completion of the finished article. Custom determines that leaves are gathered in the correct weather conditions. Leaf blades other than the rito (center leaf in the fan) and the awhi rito (the two leaves on either side of the rito) are harvested. The maintenance of the three central leaves ensures that future growth of the fan is perpetuated and all disused leaf cuttings were traditionally returned to the plant, or pā harakeke. The latter is no longer practiced in some areas of New Zealand, where insect infestation among the mulch layer has become problematic to harakeke plants due to the loss of many native ground foraging birds. 


\section{McCallum \& Carr - Identification and Use of Plant Material for the Manufacture of New Zealand Indigenous Woven Objects}

Leaf preparation for raranga (Pendergrast 1987, 2005, Puketapu-Hetet 1989, Te Kanawa 1992).

The thumb-nail is used to split and remove the edges and midrib of leaves. The remaining leaf is sized by splitting lengthwise, creating whenu for raranga. Whenu are softened and residual leaf moisture is removed using the hapine method, which involves running whenu over the back of a knife, or similar surface. Whenu are then tied into bundles and boiled in water for approximately three minutes and can be woven immediately, or once hung and sun-dried, stored indefinitely in moisture free conditions. Additionally, whenu can be dyed either traditionally using preparations from various natural sources or with modern fabric dyes.

\section{Fiber preparation for whatu (Pendergrast 1987, 2005, Puketapu-Hetet 1989, Te Kanawa 1992)}

While whenu are in the green state, a cut is made on the dull or underside of the leaf, width wise, slicing only part way through. Using a mussel (Mytilus spp.) shell to haro (scrape) the leaf strips, the shell is pulled along the strip using a technique that separates the epidermis or the green toreka (refuse), also known as para among some North Island tribes, from the whitau additionally referred to as muka. Lengths of whītau are rolled into two-ply whenu (warp yarn) and aho (weft yarn), washed and beaten ready to be hand woven into weruweru (garment(s), clothing).

\section{Use}

"[T]here is a plant which deserves notice here, as the natives make their garments of it, and it produces a fine, silky flax, superior in appearance to anything we have, and probably at least as strong. It grows everywhere..." (Cook 1785)

There are approximately 250 Phormium cultivars, many of which are ornamental (Heenan 1991). Not all harakeke cultivars are suitable for raranga due to brittle leaves, or for whatu because they possess minimal useful fiber. Wharariki (Phormium cookianum Le Jol., mountain flax) are not commonly used by Māori due to long, droopy leaves and coarse, fragile fibers (Hutton 1871). In the 1960s Rene Orchiston travelled through the North Island (NZ) collecting plants from Māori weavers; these cultivars, the Rene Orchiston Collection, form part of the (living) National New Zealand Flax Collection (Manaaki Whenua, Lincoln, South Island, NZ) (Scheele 2005). This assemblage of plants is important because they were cultivated by Māori specifically for raranga and whatu (Scheele 2005).

"Flax, that invaluable asset in the Maori economy . . . is indifferently called harakeke or harareke, while the dressed flax is whitau (pronounced "feetow")." (Beattie 2002:95)
Both the prepared strips of harakeke leaf and prepared whītau (processed fiber extracted from harakeke) have the same terminology in Māori, therefore in this article, the authors have distinguished these for the reader by referring to them as whenu harakeke (strands of flax leaf) and whenu whitau (strands of flax fiber) respectively. Both types of whenu are still used by contemporary Māori for manufacturing a wide range of objects including apparel, footwear, baskets, mats, belts, fishing nets, sails and cordage.

Kete (baskets, bags) and whariki (mats) are woven by interlacing whenu harakeke using raranga techniques. Kete and whariki may be intricately woven with various patterns of dyed or natural strands (Pendergrast 1987, 2005). However, some kete are made entirely from whenu whītau. Kupenga (nets) are also made from whenu, but rather than employing a raranga method knots are used (Pendergrast 2005, Te Rangi Hiroa 1926).

A wide range of weruweru (clothing) were and are still produced, and are discussed in following paragraphs to aid the identification of the likely cultural materials used. Probably the most familiar Māori garments are cloaks or capes. There is divergent literature regarding the terminology for cloaks and capes in te reo Māori (language); tribal cloak nomenclature varies across New Zealand. However, the words kākahu, and kahu are commonly used, as well as other names for specific classes of cloak / cape (see below). The English definitions of these two garments is also confusing e.g., The Oxford English Dictionary states that a cloak is a sleeveless outdoor overgarment hanging loosely from shoulders, whilst a cape is a sleeveless cloak especially a short one or a part of a longer cloak falling loosely from a neckband. In this article the authors will refer to cloaks and / or capes as kākahu, which is widely used in southern New Zealand. Whenu whitau are the main weaving material used in nearly all kākahu with other ornamental and / or functional materials worked into the kaupapa (foundation) of these garments, which often include intricate tāniko (finger weaving using chevron motifs) woven borders (Hirini Moko Mead 1999). However, several other kinds of decoration are used on kākahu; the most common decorative attachments are hukahuka (tags, tassels) and huruhuru (feathers) (Evans \& Ngarimu 2005, Pendergrast 1987). Hukahuka are diverse, the most widely found are those on korowai which are cloaks incorporating black dyed twisted thrums of whïtau. Other hukahuka include several if not all of the flora utilized in weaving, more especially those that shed water being used for the manufacture of pōkeka (rain capes / cloaks) (Evans \& Ngarimu 2005, Pendergrast 1987). Pōkeka is a southern word, elsewhere in New Zealand rain capes / cloaks are referred to as pākē. Other specific types of kākahu Māori include kākahu tāniko - plain cloak with tāniko border; kākahu ihupuni - dogskin cloak; kākahu tōpuni - feather cloak of kiwi (Apteryx spp.) or toroa (Diomedea spp., albatross), however other feathers can be used; kākahu and / or 
pōkeka tikumu - kaupapa of whītau with wharawhara (the white fluffy underside of the Celmisia leaf, botanically termed tomentum) extracted from tikumu (mountain daisy); and kākahu houi - cloak made from the inner bark of the lacewood (Beattie 1994). When manufacturing cloaks the work was traditionally suspended between two turuturu (weaving pegs). Nowadays a simple frame is used.

Rāpaki are garments akin to a kilt (in that it crosses over itself and wraps around the wearers waist) made from whitau they extended from the waist to the knees and traditionally worn over maro (loin cloths) (Beattie 1994, Williams 1971). Maro are often anthropologically referred to as aprons, and made of soft whītau (Beattie 1994). More commonly observed "kilts" are piupiu, made from specific harakeke cultivars (Beattie 1994, Hopa 1975, Scheele \& Walls 1994). Whenu are prepared similarly to raranga, excluding hapine which is the process of softening the whenu. While green these strips are marked out in a pattern and portions of each whenu are scraped to reveal the leaf fiber. Once dry the whenu curl width-wise in a cylindrical fashion, resembling porcupine quills. One end of each strand is stripped exposing the whitau, and then strands are plaited together forming the waistband. Piupiu are dyed black, the dye adhering only to the fibrous material with the curled leaf remaining its natural color. Other kilts include kinikini, made from alternating strips of harakeke, some 'dressed' while the remainder are left to curl. In the south, kinikini were often manufactured from houī bark (Beattie 1994).

Whenu whītau are used to manufacture taura (cord, rope) by a process called whiri. Māori used a huge variety of cordage and ropes while travelling to gather mahinga kai (food resources) e.g., in housing and lashing of canoes (Pendergrast 2005, Te Rangi Hiroa 1924). Taura vary in width and length depending on the purpose, the braiding being named from the number of whenu whitau contained in each whiri e.g., three-ply, four-ply etc. Tatua (belts) were constructed using similar methods.

Pāraerae (sandals) were made of whenu harakeke and were commonly worn in conjunction with tāupa-tāhau (leggings) to protect the wearer against inclement weather and the prolific thorn bearing shrubs that grow inland (Beattie 1994, Te Rangi Hiroa 1924).

Not only the green leaves of the harakeke were used to make objects, but often the koka or fallen dead or dried leaves from the plant were also used.

“'Koka' would be cut and beaten (patu) between two stones (pōhatu) and then steeped in water for two to three days - ka potia roto wai. It was then washed (horoi) and then spread out (horahia) in the sun until dried sufficiently, when it was taken and woven (whatu) into a garment" (Beattie 1994:47).
Tİ KŌUKA

COMMON NAME: Cabbage tree, palm lily, Cornish palm BOTANICAL NAME: Cordyline australis (Forst. f.) Hook. f. FAMILY: Asparagaceae

\section{Habitat and distribution}

Ti kōuka grows well in wide ranging environments e.g., open spaces, forest margins, and in swamps. Trees can grow to $20 \mathrm{~m}$ tall, but are typically $12 \mathrm{~m}$ tall (Moore \& Edgar 1970). The stem of young trees is typically $5-10 \mathrm{~cm}$ in diameter and for older trees, which are generally manybranched, up to $1.5 \mathrm{~m}$ (Moore \& Edgar 1970). Leaves are typically 30-100 cm x 3-6 cm (Moore \& Edgar 1970). Stiffness and color of leaves varies across provenance. Clusters of small, white flowers ( $\sim 5 \mathrm{~mm}$ long) form on multibranched penduncles (Moore \& Edgar 1970).

\section{Harvesting and processing (Beattie 1994, Puketapu-Hetet 1989, Simpson 2000)}

Green leaf was cut, the strong midrib removed, and then leaves were sized similarly to whenu harakeke. No other procedure except for boiling the whenu was undertaken and the leaf was woven immediately least it dry. Unlike harakeke whenu, tī cannot be rehydrated.

Ti fiber can be obtained by fresh water retting dead leaves that have fallen from trees. After approximately one year of steeping the epidermis is removed by gentle hand rubbing of the leaf material exposing the fibers. Alternatively, leaves were beaten to release the fiber.

\section{Use}

Tì kōuka is extremely durable in both leaf and fiber form; the strong fiber does not shrink in either fresh or saline water. Pakipaki was a kilt made of tī leaves predominantly worn by women. However, the fiber was also woven into tāpahu (cloaks used for protection in war), which were normally constructed entirely from dogskin (Best 1899, Simpson 2000). Ti was preferred over harakeke for the manufacture of tāupa tāhau and pāraerae due to increased strength often weaving double soles and called torua. Additionally, tī fiber was employed in making taura and for sewing sails together.

\section{HOUĪ, HOUHERE}

COMMON NAME: Lacebark, Long-leaved lacebark, Narrow-leaved lacebark, Mountain ribbonwood

BOTANICAL NAME: Hoheria populnea A. Cunn., Hoheria lyallii Hook. f., Hoheria glabrata Sprague \& Summerh.. FAMILY: Malvaceae

\section{Habitat and distribution}

H. populnea $(10 \mathrm{~m})$ is endemic north of the Waikato (North Island, NZ), but is naturalized throughout New Zealand 


\section{McCallum \& Carr - Identification and Use of Plant Material for the Manufacture of New Zealand Indigenous Woven Objects}

and grows in coastal and montane habitats in association with kauri (Agathis australis (D. Don) Loudon) and pōhutukawa (Metrosideros excelsa Gaertn.) (Allan 1982, The New Zealand Plant Conservation Index 2009). H. lyallii is a subalpine and montane tree $(6 \mathrm{~m})$ growing on Mt. Taranaki (North Island) and east of the main divide in the South Island (Allan 1982, The New Zealand Plant Conservation Index 2009). H. glabrata (10 m) thrives in sunny, damp sites west of the main divide in the South Island and in Central Otago (South Island) (Allan 1982, The New Zealand Plant Conservation Index 2009).

\section{Harvesting and processing}

Weavers harvest houī cork cambium or kiri houī which Beattie discusses along with

"The kauheke ... is a small tree like an apple tree and its bark could be used the same as houi (ribbonwood) to make kopare (head bindings) and piupiu." (Beattie 1994:122)

Houĩ has a lacy appearance; hence, the common name lacebark. The inner bark of houi is harvested from the sunny side of living trees: two horizontal cuts are made in the outer bark; a vertical cut made half way along the length of these; the bark peeled away and the inner houi bark removed in layers; and the outer layer is then closed like shutters on windows (Williams 2005). Additional to this sustainable practice is the method of

"rub[bing] soil from the base of the tree into the scar to seal the sap and close the bark shutter doors. Wrap a bandage around the tree trunk holding the outer bark in place and this will naturally seal over time." (McCallum 2008:55)

\section{Use}

Monro commented on the great tenacity (strength) of strips of houī, although no actual data was provided (Monro 1868); this observation may explain the use of houi in sails (Beattie 1994). Weavers harvest kiri houĩ as a resource for clothing, including kinikini. Other objects traditionally manufactured include kete, fishing nets, ropes, linings of kākahu and pōkeka; kākahu-houī, kopare (fillets: hair-binding or head-band), kopare-pōtae (mourning hats also known as parepare and kopare-taki) and tatau (Beattie 1994, Te Rangi Hiroa 1923). Tuhoe people (North Island tribe) used lacebark to manufacture slings for carrying babies (Best 1907).

\section{TIKUMU}

COMMON NAME: Mountain daisy, Cotton plant, Shepherd's daisy, Leather plant.

BOTANICAL NAME: Celmisia spp.

FAMILY: Asteraceae

\section{Habitat and distribution}

Tikumu is used to describe a number of large-leaved Celmisia spp. which are found in sub-alpine and alpine regions (Moore \& Edgar 1970). A number of species were and are still used by Māori. These species have recently been described (Lord et al. 2010). The large mountain daisies that are commonly used include the three subspecies of Celmisia semicordata Petrie $(25-70 \mathrm{~cm} \times 230$ $420 \mathrm{~cm})$, Celmisia coriacea Hook. f. (35-55 cm x 28-400 $\mathrm{cm})$ and Celmisia monroi Hook. f. (25-32 cm x 220-550 $\mathrm{cm})$; leaves are typically elongated ellipses silver-grey in color (Lord et al. 2010).

\section{Harvesting and processing}

After the flowering period, leaves are gathered from the base of the plant; the central growing floret is left (McCallum 2008). Whole leaves are dried for use, or alternatively wharawhara is peeled off from freshly harvested leaves and used (the green residue is rejected) (Beattie 1994).

\section{Use}

Tikumu was an important weaving plant used by southern Māori (McCallum 2008). A pōkeka tikumu is a rainproof cloak of whītau and tikumu leaves; whenu whītau are woven with rows of tikumu leaves attached with aho (Beattie 1994). Traditionally, wharawhara was plaited into the kaupapa. Poho taupā (chest shields) and tāhau taupā were made of tikumu, and were reputed to offer excellent protection (Beattie 1994). Twisted wharawhara were used to make fishing line and moccasins (Monro 1868).

Tōī

COMMON NAME: Mountain cabbage tree, broad leaf cabbage tree

BOTANICAL NAME: Cordyline indivisa (Forst.f.) Steud.

FAMILY: Asparagaceae

\section{Habitat and distribution}

Tōì grows in wet, open spaces in forests in the north-west and west mountainous regions of the South Island of New Zealand. Tōì grow to $8 \mathrm{~m}$ tall and are rarely branched (Moore \& Edgar 1970). Typical leaf size is $10-15 \mathrm{~cm} \times 1-2$ $\mathrm{m}$ with a prominent red midrib (Moore \& Edgar 1970). The penducle is hidden under the leaves and is typically $\sim 30$ $\mathrm{cm} \times 60-160 \mathrm{~cm}$, flowers are $\sim 6 \mathrm{~mm}$ long and bluish in color (Moore \& Edgar 1970).

\section{Harvesting and processing}

Generally only enough growing tōī leaf is harvested for one days weaving as once the leaf dries the vegetable matter is not so easily disengaged from the fiber (Best 1899). This is obtained by first removing the midrib then beating the leaves with a stone pounder to soften and re- 
move the fiber. In a more contemporary context the authors have extracted fiber from fallen dry leaves after steeping in water.

\section{Use}

The uses of tōì are analogous to that of tī kōuka, although kākahu and other articles woven from tōī possess a much coarser fiber. This was the preferred fiber for constructing warrior cloaks, which were dyed entirely black on completion (Pendergrast 1987).

\section{KIEKIE \\ BOTANICAL NAME: Freycinetia banksii A.Cunn. \\ FAMILY: Pandanaceae}

\section{Habitat and distribution}

Kiekie is a densely branched, woody climber of rain-forest and coastal-scrub trees; the stems are up to $4 \mathrm{~cm}$ in diameter, and the leaves are tufted and arranged spirally $(2-2.5 \mathrm{~cm}$ x $150 \mathrm{~cm}$ ) (Moore \& Edgar 1970, The New Zealand Plant Conservation Index 2009). Leaf bases are pale while leaves are pleated and triangular in cross-section (The New Zealand Plant Conservation Index 2009).

\section{Harvesting and processing (McCallum 2008, Pendergrast 1987)}

Growing clumps are twisted and broken off from the main stem. The correct time to do this varies, however, kiekie will not detach from its stem unless it is 'ready' to be harvested. Leaves for weaving are separated from the clump and sorted into lengths. The midrib removed by piercing the blade on either side then run the fingers along the length of the leaf. Lengths of material are tied together, boiled in water for five minutes, left in running water overnight and hung in the sun until bleached. The bundles are often dyed then stored ready for future use. Kiekie fiber is obtained by retting in water until it is soft enough to miri (rub) the leaf removing the refuse green leaf matter or toreka. By placing the leaves in an umu or hangi (earth oven that cooks using steam) it hastened the rotting of the epidermal layer.

\section{Use}

Kiekie is a much sought after weaving plant as it requires little preparation and dries white. Kiekie fiber was used for tāniko and in whatu for making garments. Leaf strips were used for making tukutuku, which are the decorative lattice work panels that adorn many meeting houses; making sails that were constructed of leaf woven similarly to a whariki and of several pieces joined together and in basketwork (Best 1976).

\section{PINNGAO}

COMMON NAME: Cutty grass, Golden Sand Sedge, Tumbleweed

BOTANICAL NAME: Ficinia spiralis (A.Rich.) Muasya \& de Lange

FAMILY: Cyperaceae

\section{Habitat and distribution}

Pīngao is a coastal sedge that binds unstable sand dunes (Kirk 1873, The New Zealand Plant Conservation Index 2009). Pìngao clums are yellow-green and stiff, golden yellow-orange when dry and have dimensions ranging 2-4 mm x 300-900 mm (Allan 1982). Size and length vary across New Zealand, leaf lengths are much shorter on the West Coast of the South Island and often much longer and wider than in the North Island.

\section{Harvesting and processing}

Fiber and leaves are prepared for weaving.

"Pingao was used for its orange color, but was only procurable in certain localities on the sandhills near the coast. The long leaves of these plants were shredded with the thumb-nail into strips of from a tenth to an eighth of an inch in width. The strips were placed in hot water and then scraped (kaku) with a shell, to remove part of the outer epidermis covering the fiber. They were then doubled over, tied into hanks, and hung up to dry... the pingao retained its rich orange color." (Te Rangi Hiroa 1921)

Leaves are softened in a solution of water and tree bark (which prevents curling), and then scraped with a shell (Riley 1994). Only a small number are scraped at a time so that the leaves do not curl before being used.

\section{Use}

Thin strips of pīngao (in combination with harakeke and kiekie) are used for the construction of tukutuku that adorn the inside walls of whare nui (meeting house) (Colenso 1881, Te Rangi Hiroa 1921, 1923). There are numerous tukutuku patterns and the reader is referred to a standard text (Te Rangi Hiroa 1921). Pīngao is also used for manufacturing highly decorated whariki and kete (Colenso 1881, Te Rangi Hiroa 1923).

\section{KUTA}

COMMON NAME: Bamboo spike sedge, Lake club-rush BOTANICAL NAME: Eleocharis sphacelata R.Br., Schoenoplectus tabernaemontani (C.C.Gmel.) Palla FAMILY: Cyperaceae

\section{Habitat and distribution}

Kuta is a word used to describe two plants: E. sphacelata and S. tabernaemontani (Ngā Tipu Whakaoranga 


\section{McCallum \& Carr - Identification and Use of Plant Material for the Manufacture of New Zealand Indigenous Woven Objects}

database 2007). In some tribal areas these two plants are distinguished by different names. Both plants grow in wet places and standing water e.g., edges of lakes, their rhizomes and lower portions of stems are immersed below water (Moore \& Edgar 1970, The New Zealand Plant Conservation Index 2009). The stem of $E$. sphacelata is typically $4-12 \mathrm{~mm}$ diameter and $30-90 \mathrm{~cm}$ tall, the stem has internal transverse compartments similar in appearance to split bamboo, these can often be observed when the stem is held up to the light, but are not visible on the outside of the stem (Moore \& Edgar 1970), which has a spikelet of approximate dimension 2-7 cm long (Moore \& Edgar 1970). In comparison, S. tabernaemontani has stems $3-10 \mathrm{~mm}$ in diameter and between 0.6 and $3 \mathrm{~m}$ long, with a spongy pith and spikelets that are $6-11 \mathrm{~mm}$ long (The New Zealand Plant Conservation Index 2009).

\section{Harvesting and processing}

Kuta is harvested during summer by cutting the growing stems below the water level at the base of the shoot. Processing of this plant depends on if it is used whole or made into whenu. According to contemporary weaver, Erenora Puketapu-Hetet, fully grown kuta stems are

"spread out and covered with old mats to flatten them. They are usually left for three days, but are frequently inspected and turned to obtain an even shade of brownish red. They are then hung to dry." (PuketapuHetet 1989:15)

\section{Use}

"Sails are said to have occasionally been made from stems of the kuwawa (syn. kuta and kutakuta)" (Best 1976:258). Although there is scant literature pertaining to kuta being used for baskets, there is a small kete, housed at the Otago Museum (Dunedin, New Zealand) made from this material. Te Rangi Hiroa (1923) states that kuta was used to make floor mats.

\section{RAUPŌ}

COMMON NAME: Bulrush

BOTANICAL NAME: Typha orientalis C.Presl

FAMILY: Typhaceae

Although not used strictly as a weaving resource, raupō played an important role in southern cultural heritage.

\section{Habitat and distribution}

Raupō is an emergent species, that is, it grows in marshy area and standing water with its roots in the sediment and leaves and flower heads emerging above the water surface. It can form large mono-specific stands or colonies (i.e., can be the dominant species in a wetland). Raupō grows actively in summer, with slow growth or dormancy in winter. The plant is found throughout New Zealand and grows 1-3 m tall, the leaves can be $30 \mathrm{~cm}$ long and have a spongy interior (Moore \& Edgar 1970).

\section{Harvesting and processing}

Raupō was traditionally harvested during the active growth period, more so in autumn when mokihi (water rafts) would be built to carry foodstuffs that had been gathered from the hinterland. Growing shoots are cut at the base beneath the water level and leaves are spread out on racks in order for them to dry evenly.

\section{Fiber preparation}

"A peculiar process was employed in some parts in order to bleach or whiten fiber to be used in the manufacture of superior garments. Roots of raupo bulrush (Typha) were procured, washed, then placed in a wooden vessel with water, in which they were crushed and pounded with a pestle of stone or hardwood. The hanks of fiber were then put in and the whole worked and pounded, a process that is said to have produced a kind of lather (pahuka). This process is said to have much improved the appearance of the fiber, some property of the bulrush root having a bleaching or cleansing effect." (Best 2005:500)

Use

The uses of raupō are wide and varied, housing, food, rongoa, making poi (string balls often seen as part of a Māori dance troupe), manutukutuku (kites) and rā (sails)

"Raupo could be used for making ra = sails. The sails were square as a rule and had a pole across the top and were hauled up the mast." (Beattie 1994:287).

Although not woven, Best comments that sails are "formed of bulrushes dried in the sun and tacked together" and that "leaves were two- ply,- - that is, a double layer of such bulrush-leaves was employed, inasmuch as that leaf is of somewhat fragile nature. The long lines or series of leaves were laid parallel to the sprit side of the sail, where the weaving commenced. The process, however, can scarcely be described as weaving, but is the one termed nati by the Maori-a method of lacing" (Best 1976:254, 260-261).

The most common use in the south was for building mokihi. These boats were made from buoyant material, such as the raupō excellent for traversing and navigating southern lakes and rivers. Accounts in Best discuss the mokihi as being built in other materials such as houama or whau (Entelea arborescens R.Br.) using pirita (Rhipogonum scandens J.R. Forst. \& G. Forst.) as lashing (Best 1976). 


\section{NEINEI}

BOTANICAL NAME: Dracophyllum traversii Hook.f., Dracophyllum elegantissimum S.Venter

FAMILY: Ericaceae

\section{Habitat and distribution}

There are many names for the various Dracophyllum spp. used by Māori, the reader is directed to specialised literature (e.g., McCallum 2008). However, the leaves of two trees - mountain neinei $(D$. traversii) and neinei $(D$. elegantissimum) are commonly used by weavers (McCallum 2008, Ngā Tipu Whakaoranga database 2007). The leaves form a candelabrum-shaped crown (The New Zealand Plant Conservation Index 2009). D. traversii typically grows $10-13 \mathrm{~m}$ in sub-alpine forests, in comparison $D$. elegantissimum grows to $14 \mathrm{~m}$ (The New Zealand Plant Conservation Index 2009).

\section{Harvesting and processing}

Neinei leaves are not cut, but dropped leaves are gathered from the base of the tree and are usually quite plentiful. Leaves are used whole and require no processing, therefore making them useful as a weaving material.

\section{Use}

The leaves of the neinei are tan in color and have the appearance of being polished or varnished. Neinei is not only decorative, but highly functional as a weatherproof cloak more popular in the South Island.

\section{Conclusion}

This article provides information on the use of plants by Māori for the manufacture of a disparate range of objects. The usual starting point of a research project for many employees of cultural institutions and members of the public is an object. Therefore, a Table is provided to assist in the identification of the likely plant used to manufacture objects, including those not commonly found (or maybe not correctly identified) in cultural institutions. Information on each of these plants is then provided; this information includes Māori and Latin names, habitat, growth characteristics, harvesting protocols, processing and a description of objects linked to that plant.

The article is written from the perspective of Māori with respect to protocol and naming of both objects and plants. In writing this article the predominant aim was to discuss selected New Zealand indigenous plants with respect to the identification of objects and their manufacture. The authors have made available information to an international audience that upholds the cultural and social identity of Māori through the interdisciplinary nature of this article. It achieves this by embracing indigenous and western knowledges and contributes to research within cultural institutions, but also the broader discipline of anthropology. The article aims to inform, assist and educate a wide range of museum staff providing further information for the discerning visitor to heritage institutions. Thus makes a significant contribution to the field of museum studies.

\section{Acknowledgements}

No funding was received for the production of this specific article. The authors acknowledge all sources of the information provided in the article. Citations to written sources are provided in the text and in the reference list. As authors we respect the cultural and intellectual property shared by the participants interviewed in the production of the initial resource kit and acknowledge each of them for their willingness to communicate their knowledge.

\section{Literature cited}

Allan, H.H. 1982. Flora of New Zealand: Indigenous Tracheophyta - Psilopsida, Lycopsida, Filicopsida, Gymnospermae, Dicotyledons. Manaaki Whenua Landcare Research, Lincoln, New Zealand.

Anderson, A.J. 2002. A fragile plenty: Pre-European Maori and the New Zealand environment. Pp. X-X in Environmental Histories of New Zealand. Edited by E. Pawson \& T. Brooking. Oxford University Press, Auckland, New Zealand.

Balázsy, Á. \& D. Eastop. 1999. Chemical Principles of Textile Conservation. Butterworth Heinemann, Oxford, U.K.

Beattie, H. 1994. Traditional Lifeways of the Southern Maori. University of Otago Press in association with Otago Museum, Dunedin.

Beattie, H. 2002. The Māoris and Fiordland. Cadsonbury Publications, Christchurch.

Best, E. 1899. The Art of the Whare Pora: Notes on the clothing of the ancient Maori, their knowledge of preparing, dyeing and weaving various fibers, together with some account of dress and ornaments, and the ancient ceremonies and superstitions of the whare pora. Transactions of the New Zealand Institute 31:625-658.

Best, E. 1907. Maori forest lore: Being some account of native forest lore and woodcraft, as also of many myths, rites, customs, and superstitions connected with the flora and fauna of the Tuhoe or Ure-wera district. Transactions and Proceedings of the Royal Society of New Zealand 40:185-254.

Best, E. 1976. The Maori Canoe. Government Printer, Wellington. 


\section{McCallum \& Carr - Identification and Use of Plant Material for the Manufacture of New Zealand Indigenous Woven Objects}

Best, E. 2005. The Māori. Volume II. www.nzetc.org/tm/ scholarly/tei-Bes02Maor.html.

Brandt, C.W. 1937. Chemistry of Phormium tenax New Zealand flax. The New Zealand Journal of Science and Technology 18(8):613-627.

Carr, D.J., N.M. Cruthers, E. Girvan \& K.S. Gould. 2009. Approaches to the identification of plant material used in Maori artefacts. Studies in Conservation 53:252-263.

Carr, D.J., N.M. Cruthers, R. Laing \& B.E. Niven. 2005. Fiber from three cultivars of New Zealand flax Phormium tenax. Textile Research Journal 752:93-98.

Colenso, W. 1881. On the fine perception of colors possessed by the ancient Maoris. Transactions and Proceedings of the Royal Society of New Zealand 14:49-76.

Cook, J. 1785. A Voyage to the Pacific Ocean. G. Nicol and T. Cadell, London.

Cross, B.D. 1912. Investigations on Phormium with Regard to the Improvement of its Economic Importance. Ph.D. thesis, University of New Zealand, Canterbury College, Christchurch, New Zealand.

Evans, M. \& R. Ngarimu. 2005. The Eternal Thread. Te Aho Mutunga Kore: The art of Maori weaving. Huia Publishers, Wellington, New Zealand.

Florian, M.L.E., D.P. Kronkight \& R.E. Norton. 1990. The Conservation of Artifacts made from Plant Materials. The J. Paul Getty Trust, Princeton University Press, Princeton, New Jersey.

Goulding, J.H. 1971. Identification of archaeological and ethnological specimens of fiber-plant material used by the Maori. Records of the Auckland Institute and Museum 8:57-101.

Heenan, P.B. 1991. Checklist of Phormium Cultivars. Royal New Zealand Institute of Horticulture Inc., Lincoln,New Zealand.

Hirini Moko Mead. 1999. Te Whatu Tāniko: Tāniko weaving technique and tradition. Reed Books, Auckland, New Zealand.

Hodges, H. 1988. Artifacts: An introduction to early materials and technology. Ronald P Frye \& Co., London.

Hopa, N. 1975. Art of Piu-piu Making: Instructional manual setting out the materials, design and assembly of the Maori skirt, central item of the Maori costume. A. H. Reed, Wellington.
Hutton, F.W. 1869. On the structure of the leaf of Phormium tenax. Transactions and Proceedings of the New Zealand Institute 2:111-117.

Hutton, F.W. 1870. A lecture on the manufacture of New Zealand flax. Presented at The Auckland Institute. Pp.8097 Report of the Commissioners Appointed to Enquire into the Preparation of the Phormium Fiber or New Zealand Flax. Appendix to the Journals of the New Zealand House of Representatives. 1871 11G(4):80-97.

Hutton, F.W. 1871. On the means of distinguishing its fibres from those of Manilla or sisal. Pp.72-74 in Phormium tenax as a Fibrous Plant. Edited by J. Hector. New Zealand Government, Wellington.

Kawharu, M. 2000. Kaitiakitanga: A Maori anthropological perspective of the Maori socio-environmental ethic of resource management. Journal of the Polynesian Society 109:349-70.

Kirk, F.L.S. 1873. Notes on the plants best adapted for the reclamation of sand wastes. Transactions and Proceedings of the Royal Society of New Zealand 6:45-54.

Lord, J.M., R.E. McCallum, C.A. Smith \& D.J. Carr. 2010. Use and identification of tikumu (Celmisia species, Asteracae) in artifacts of New Zealand origin. Journal of the American Institute for Conservation 49(Fall/Winter):69-82.

McCallum, R.E. 2008. He Kete Taoka. Komiti Taoka Tuku Iho, Dunedin, New Zealand.

Monro, D. 1868. On the leading features of the geographical botany of the provinces of Nelson and Marlborough, New Zealand. Transactions and Proceedings of the Royal Society of New Zealand 1:6-17.

Moore, L.B. \& E. Edgar 1970. Flora of New Zealand: Indigenous Tracheophyta - Monocotyledons except Graminae. Manaaki Whenua Landcare Research, Lincoln, New Zealand.

New Zealand Government. 1998. Ngāi Tahu Claims Settlement Act 1998. www.legislation.govt.nz/act/public/1998/0097/latest/DLM429090.html.

Ngā Tipu Whakaoranga database. 2007. Ngā Tipu Whakaoranga database. http://maoriplantuse.landcareresearch.co.nz/WebForms/default.aspx.

Nottidge, T. 1869. On the structure and colour of the fibre of Phormium tenax. Transactions and Proceedings of the New Zealand Institute 2:108-111.

O'Regan, G. 1997. Bicultural Developments in Museums of Aotearoa: What Is the current status? Ki Te Whakamana I Te Kaupapa Tikanga-a-Rua Ki Roto o Ngā Whare 
Taonga o te Motu: Kei hea e tū ana? Museum of New Zealand Te Papa Tongarewa National Services, Wellington.

Pendergrast, M. 1987. Te Aho Tapu: The sacred thread traditional Maori weaving. Reed Methuen, Auckland, New Zealand.

Pendergrast, M. 2005. Maori Fiber Techniques: $A$ resource book for Maori fiber arts. Ka Tahi: Hei tama tu tama. Reed Publishing NZ Ltd., Auckland, New Zealand.

Puketapu-Hetet, E. 1989. Maori Weaving. Pitman, Auckland, New Zealand.

Riley, M. 1994. Maori Healing and Herbal. Viking Sevenseas NZ Ltd., Paraparaumu, New Zealand.

Scheele, S. 2005. Harakeke the Rene Orchiston Collection. 3rd edition. Manaaki Whenua Press, Lincoln, New Zealand.

Scheele, S. \& G. Walls 1994. Harakeke The Rene Orchiston Collection. Manaaki Whenua Press, Lincoln, New Zealand.

Simpson, P. 2000. Dancing Leaves. The story of New Zealand's cabbage tree, ti kouka. Canterbury University Press, Christchurch, New Zealand.

Te Kanawa, D. 1992. Weaving a kakahu. Wellington, Bridget Williams Books in association with Aotearoa Moananui a Kiwa Weavers.

Te Rangi Hiroa. 1921. Maori decorative art: no. 1, housepanels arapaki, tuitui, or tukutuku. Transactions and Proceedings of the Royal Society of New Zealand 53:452470.

Te Rangi Hiroa. 1923. Maori plaited basketry and plaitwork: I, mats, baskets, and burden-carriers. Transactions and Proceedings of the Royal Society of New Zealand 54:705-742.

Te Rangi Hiroa. 1924. Maori plaited basketry and plaitwork: 2, belts and bands, firefans fly-flaps, sandals and sails. Transactions and Proceedings of the Royal Society of New Zealand 55:344-362.

Te Rangi Hiroa. 1926. The Maori craft of netting. Transactions and Proceedings of the Royal Society of New Zealand 56:597-646.

The New Zealand Plant Conservation Index. 2009. The New Zealand Plant Conservation Index. www.nzpcn.org. $\mathrm{nz} /$.

Williams, T. 1971. Dictionary of the Maori Language. Advisory Committee on the Teaching of the Maori language, Department of Education, Wellington.
Williams, T. 2005. Personal communication to D.J. Carr: Harvesting houi. Moeraki 17 July.

\section{Additional Reading List}

Anderson, A.J. 1998. A Welcome of Strangers: An ethnohistory of Southern Maori A.D. 1650-1850. University of Otago Press, Dunedin.

Anderson, A.J. 2002. A fragile plenty: pre-European Maori and the New Zealand environment. Pp.19-34 in Environmental Histories of New Zealand. Edited by E. Pawson \& T. Brooking. Oxford University Press, Auckland, New Zealand.

Beattie, H. 1994. Our Southernmost Māoris. Cadsonbury Publications, Christchurch, New Zealand.

Beattie, H. 1994. Māori Lore of Lake, Alp and Fiord. Cadsonbury Press, Christchurch, New Zealand.

Best, E. 2005. Forest Lore of the Māori: With methods of snaring, trapping, and preserving birds and rats, uses of berries, roots, fern-root, and forest products, with mythological notes on origins, karakia used etc. Te Papa Press, Wellington.

Best, E. 1974. The Māori as he was: A brief account of Māori life as it was in pre-European days. Government Printer, Wellington.

Buck, P. 1987. The Coming of the Māori. Whitcoulls Ltd., Wellington.

Carr, D. \& R. McCallum. 2009. Turuturu: Integrating indigenous and western knowledge. Alternative 5(1):88-107.

Dacker, B. 1990. The People of the Place: Mahika kai. New Zealand 1990 Commission, Wellington.

Evison, H. 1993. Te Wai Pounamu, The greenstone island: a history of the southern Māori during the European colonisation of New Zealand. Aoraki Press, Wellington.

Mead, S.M. 1968. Te Whatu Taaniko. Reed Publishers Ltd., Wellington.

Orbell, M. 1985. The Natural World of the Māori. David Bateman Ltd., Auckland.

Riley, M. 2001. Māori Bird Lore. An introduction. Viking Sevenseas, Paraparaumu, New Zealand.

Stack, J.W. 1898. South Island Maoris: A sketch of their history and legendary lore. Whitcombe \& Tombs, Christchurch, New Zealand. 


\section{McCallum \& Carr - Identification and Use of Plant Material for the Manufacture of New Zealand Indigenous Woven Objects}

\section{Glossary}

\begin{tabular}{|c|c|}
\hline aho & weft yarn, thread \\
\hline atua & $\mathrm{god} / \mathrm{s}$ \\
\hline awhi rito & $\begin{array}{l}\text { two leaves either side of the center } \\
\text { leaf in a fan of flax }\end{array}$ \\
\hline hangi (see umu) & earth oven \\
\hline hapine & $\begin{array}{l}\text { process to soften whenu and re- } \\
\text { move moisture }\end{array}$ \\
\hline harakeke & $\begin{array}{l}\text { Phormium tenax, New Zealand } \\
\text { lowland flax }\end{array}$ \\
\hline haro & scrape \\
\hline $\begin{array}{l}\text { hauma (see } \\
\text { whau) }\end{array}$ & Entelea arborescens \\
\hline Hāwea & a southern tribal group \\
\hline horahia & spread out \\
\hline horoi & wash \\
\hline houī, houhere & Hoheria spp., lacebark \\
\hline hukahuka & tags \\
\hline huruhuru & feathers \\
\hline iwi & tribe, bone, people \\
\hline iwi Māori & Māori people, Māori tribes \\
\hline ka potia roto wai & steeped in water \\
\hline kahu & cloak / cape \\
\hline kaitiaki & caretaker \\
\hline kaitiakitanga & guardianship \\
\hline kākahu & cloak / cape \\
\hline kākahu houi & $\begin{array}{l}\text { cloak made from the inner bark of } \\
\text { the lacewood }\end{array}$ \\
\hline kākahu ihupuni & dogskin cloak \\
\hline kākahu Māori & Māori cloaks \\
\hline kākahu tāniko & chevron motif bordered cloak \\
\hline kākahu tōpuni & feather cloak \\
\hline kaku & scrape \\
\hline kaumātua & elders \\
\hline kauri & Agathis australis \\
\hline kaupapa & foundation \\
\hline kete & bag, basket/s \\
\hline kiekie & Freycinetia banksii \\
\hline kinikini & type of kilt \\
\hline kiri houī & inner bark of the Hoheria spp. \\
\hline kiwi & Apteryx spp. \\
\hline koka & fallen dead or dried flax leaves \\
\hline koladi, kōrari & flax flower stalk \\
\hline
\end{tabular}

\begin{tabular}{|c|c|}
\hline kopare & head band \\
\hline kopare pōtae & mourning hat/s \\
\hline korowai & cloak with twisted black thrums \\
\hline kupenga & net/s \\
\hline $\begin{array}{l}\text { kuta, kuwawa, } \\
\text { kutakuta }\end{array}$ & $\begin{array}{l}\text { Eleocharis sphacelata, Schoeno- } \\
\text { plectus tabernaemontani }\end{array}$ \\
\hline mahinga kai & cultural resources, food resources \\
\hline mana & prestige \\
\hline manutukutuku & kites \\
\hline Māori & $\begin{array}{l}\text { indigenous population of } \mathrm{New} \\
\text { Zealand }\end{array}$ \\
\hline maro & loin cloth/s \\
\hline $\begin{array}{l}\text { mātauranga } \\
\text { Māori }\end{array}$ & traditional knowledge \\
\hline miri & rub, massage \\
\hline mokihi & temporary rafts \\
\hline neinei & Dracophyllum elegantissimum \\
\hline Ngāi Tahu & a southern tribal group \\
\hline Ngāti Māmoe & a southern tribal group \\
\hline pā harakeke & flax plantation \\
\hline pāhuka & froth, foam, lather \\
\hline pākē & rain cloaks / capes \\
\hline Pākehā & non-Māori \\
\hline pakipaki & a type of kilt \\
\hline pāraerae & sandles \\
\hline patu & beat \\
\hline pīngao & $\begin{array}{l}\text { Desmoschoenus spiralis, sand } \\
\text { sedge }\end{array}$ \\
\hline pirita & $\begin{array}{l}\text { Rhipogonum scandens, supple- } \\
\text { jack }\end{array}$ \\
\hline piupiu & type of kilt \\
\hline pōhatu & stone/s \\
\hline poho taupā & chest shield/s \\
\hline pohutukawa & Metrosideros excelsa \\
\hline poi & string balls \\
\hline pōkeka & rain cloaks \\
\hline pōkeka tikumu & $\begin{array}{l}\text { rain cloaks made from the Cemisia } \\
\text { spp. }\end{array}$ \\
\hline rā & sails \\
\hline rāpaki & a kilt \\
\hline Rapuwai & a southern tribal group \\
\hline rāraki kōrero & traditional stories \\
\hline
\end{tabular}




\begin{tabular}{|l|l|}
\hline raranga & weaving using leaf strips \\
\hline raupō & Typha orientalis, bulrush \\
\hline rito & center leaf in the fan \\
\hline rohe & tribal areas \\
\hline rongoa & medicine/s \\
\hline rourou & $\begin{array}{l}\text { basket used for eating from e.g., a } \\
\text { plate }\end{array}$ \\
\hline tāhau taupā & forearm guards \\
\hline tāniko & $\begin{array}{l}\text { finger weaving employing chevron } \\
\text { motifs }\end{array}$ \\
\hline taonga, taoka & treasure/s, treasured objects \\
\hline taonga tuku iho & treasures handed down \\
\hline tāpahu & $\begin{array}{l}\text { cloak used for protection during } \\
\text { war }\end{array}$ \\
\hline tapu & under restriction \\
\hline tatua & belt/s \\
\hline tāupa-tāhau & leggings \\
\hline taura & cordage \\
\hline te reo Māori & language \\
\hline Te Wai Pounamu & South Island of New Zealand \\
\hline tikanga & custom/s, protocol/s \\
\hline tī kōuka & Cordyline australis \\
\hline tikumu & Clemisia spp., mountain daisy \\
\hline tohunga & Skilled person/s \\
\hline tōī & $\begin{array}{l}\text { Cordyline indivisa, mountain cab- } \\
\text { bage tree }\end{array}$ \\
\hline
\end{tabular}

\begin{tabular}{|l|l|}
\hline toreka & leaf refuse \\
\hline toroa & Diomedea spp. \\
\hline torua & double sole of footwear \\
\hline Tuhoe & a North Island tribal group \\
\hline tukutuku & decrorative lattice work panel \\
\hline turuturu & weaving pegs \\
\hline uaka & a southern term for seed pods \\
\hline umu (see hangi) & earth oven \\
\hline Waitaha & a southern tribal group \\
\hline weruweru & garment/s, clothing \\
\hline whakapapa & genealogy \\
\hline wharariki & $\begin{array}{l}\text { Phormium cookianum, New Zea- } \\
\text { land mountain flax }\end{array}$ \\
\hline wharawhara & $\begin{array}{l}\text { white fluffy underside of tikumu } \\
\text { leaf, tomentum }\end{array}$ \\
\hline whare nui & meeting house \\
\hline whariki & mats \\
\hline whatu & weaving with fiber \\
\hline $\begin{array}{l}\text { whau } \\
\text { (see hauma) }\end{array}$ & Entelea arborescens \\
\hline whenu & $\begin{array}{l}\text { strand/s, warp yarn } \\
\text { cessed fiber extracted from hara- } \\
\text { keke }\end{array}$ \\
\hline whiri & \\
\hline whītau & braid \\
\hline
\end{tabular}

